\title{
Using pingers to reduce bycatch of small cetaceans in Peru's small-scale driftnet fishery
}

\author{
Jeffrey C. Mangel, Joanna Alfaro-Shigueto, Matthen J. Witt \\ David J. Hodgson and Brendan J. GodLeY
}

\begin{abstract}
There is growing awareness that small-scale fisheries may have large impacts on threatened marine fauna. Bycatch of small cetaceans by the Peruvian smallscale driftnet fleet results in the deaths of thousands of animals annually. We sought to assess the effectiveness of acoustic alarms (pingers) for reducing the incidental capture of dolphins and porpoises by this fleet. Fortythree experimental trips (156 fishing sets) and 47 control trips (195 fishing sets) out of Salaverry Port, northern Peru, were observed from April 2009 to August 2011. Twenty-two percent of control sets captured small cetaceans (67 individuals) and $16 \%$ of experimental sets had captures of small cetaceans (33 individuals). The bycatch rate of experimental sets was 0.50 individuals $\mathrm{km}^{-2} \mathrm{~h}^{-1}$, whereas for control sets the rate was 0.80 individuals $\mathrm{km}^{-2} \mathrm{~h}^{-1}$. This $37 \%$ reduction in bycatch rate suggests that pingers may be effective in reducing the bycatch of small cetaceans in this fishery. Catch rates of the fishery's target shark and ray species were unchanged. Given the vast size of this fishery and its current levels of bycatch of small cetaceans $(>10,000$ individuals annually), even the modest declines in bycatch we observed could result in reductions in mortality of hundreds or thousands of small cetaceans per annum. Challenges, including increased costs, to large-scale utilization of pingers have yet to be overcome. The harpooning of dolphins for use as bait will also need to be addressed for further reductions in dolphin and porpoise bycatch and mortality to be achievable.
\end{abstract}

Keywords Bycatch, catch per unit effort, gill-net, Peru, pinger, shark, small cetacean, small-scale fishery

\section{Introduction}

mall-scale fisheries are globally important as food $\checkmark$ providers and as sources of employment in many coastal communities, particularly in the developing world

JefFrey C. MANGeL ${ }^{*}$ (Corresponding author), JoAnna Alfaro-Shigueto*, Matthew J. Witt $\dagger$, David J. Hodgson and Brendan J. Godley Centre for Ecology and Conservation, University of Exeter, Penryn, Cornwall, TR10 9EZ, UK. E-mail jcm210@exeter.ac.uk

*Also at: ProDelphinus, Lima, Peru

$\dagger$ Also at: Environment and Sustainability Institute, University of Exeter, Penryn, Cornwall, UK

Received 20 January 2012. Revision requested 2 March 2012

Accepted 9 May 2012. First published online 10 May 2013
(Berkes et al., 2001; McGoodwin, 2001; Béné, 2006; Chuenpagdee et al., 2006). Unlike industrial fisheries, which are more centralized and often have more defined management structures, small-scale fisheries are frequently characterized by political and economic marginalization and are often subject to minimal management and enforcement mechanisms (Berkes et al., 2001; McGoodwin, 2001; Dutton \& Squires, 2008; Jacquet \& Pauly, 2008). A growing list of recent studies shows that small-scale fisheries can have significant levels of incidental catch (bycatch) of marine fauna (e.g. Moreno et al., 2006; Jaramillo-Legorreta et al., 2007; Peckham et al., 2007; Mangel et al., 2010; Alfaro-Shigueto et al., 2011). Attempts to address bycatch in these fisheries (e.g. through introduction of mitigation measures or time-area closures) are challenging (Lewison et al., 2004; Campbell \& Cornwelles, 2008; Soykan et al., 2008).

The bycatch of small cetaceans has been reported in many fisheries worldwide (Jefferson \& Curry, 1994; Perrin et al., 1994; Reeves et al., 2003; Read et al., 2006). Small-scale fisheries are likely to contribute significantly to this bycatch (Read et al., 2006; Read, 2008). Gill-net fisheries in particular are widely regarded as some of the largest sources of small cetacean mortality (Jefferson \& Curry, 1994; Dawson \& Slooten, 2005; Read et al., 2006; Read, 2008).

The use of acoustic alarms is seen as one of the few potential solutions to gill-net bycatch (Read, 2008). Acoustic alarms, or pingers, are small battery-powered devices attached at intervals along a net that emit a repeated signal audible to small cetaceans. Pingers are successful at reducing the bycatch of many cetacean species (e.g. Kraus et al., 1997; Bordino et al., 2002; Barlow \& Cameron, 2003; Carretta et al., 2008; Palka et al., 2008) and their use is now a required bycatch mitigation measure in several commercial net fisheries in the USA and Europe (NOAA \& NMFS, 1997, 1998; European Commission, 2004).

In Peru fishery interactions with small cetaceans have been reported since the 1960s (Clarke, 1962; Read et al., 1988; Van Waerebeek \& Reyes, 1990). The majority of interactions were of small cetaceans caught by the small-scale gill-net fleet and the annual take was estimated at 10,000-20,000 individuals (Read et al., 1988; Van Waerebeek \& Reyes, 1990, 1994). Ministerial decrees in 1990 and 1994 (Decree Nos 569-90-PE and 321-94-PE) were followed by a national law in 1996 banning the capture of and trade in small cetaceans (Law No. 26585, 9 April 1996). Subsequent monitoring indicated that small cetaceans were still being killed in 
Peru's small-scale fisheries but reporting was limited (Van Waerebeek et al., 1997, 2002). Using on-board observers on driftnet vessels from the northern Peru port of Salaverry, Mangel et al. (2010) reported that bycatch of small cetaceans was still common and suggested that capture rates may remain at levels seen before the 1996 ban. This study further noted that a large percentage of this bycatch was discarded, suggesting an opportunity to introduce bycatch mitigation measures, such as pingers, to the fishery. The purpose of our study was to assess the effect of pingers on bycatch of small cetaceans and on target catch within the Peruvian small-scale driftnet fishery.

\section{Methods}

\section{The fishery}

Small-scale (artisanal) vessels are defined according to Peruvian fishery regulations as those with a maximum of $32.6 \mathrm{~m}^{3}$ of storage capacity, $<15 \mathrm{~m}$ in length, and principally relying on the use of manual work during fishing operations (Ley General de Pesca, 2001). During April 2009-August 2011 small-scale driftnet fishing trips were monitored out of the port of Salaverry in northern Peru. Vessels in this fishery set multifilament nets at the ocean surface during the late afternoon and recover the nets the following morning after a soak time of c. 13 hours. Nets are typically $1.5-2 \mathrm{~km}$ long and have a stretched mesh of 19.1-25.4 cm, and remain attached to the drifting vessel during the set. This fleet operates almost exclusively over Peru's continental shelf and targets shark and ray species (primarily smooth hammerhead Sphyrna zygaena, blue Prionace glauca, short-fin mako Isurus oxyrinchus and thresher Alopias vulpinus sharks, and eagle rays Myliobatis spp.), although other species are captured incidentally, including sea turtles (Alfaro-Shigueto et al., 2011), seabirds (Awkerman et al., 2006), swordfish Xiphias gladius, dolphinfish Coryphaena hippurus and manta rays Manta birostris. The blubber of small cetaceans is regularly used as bait in this fishery because of durability and perceived effectiveness at improving the catch of blue and mako sharks (Mangel et al., 2010). This bait is derived from harpooned individuals or from bycatch recovered during the trip. Detailed descriptions of this fishery and its capture species can be found in Mangel et al. (2010), AlfaroShigueto et al. (2010) and Table 1.

\section{Experimental design}

For the purposes of this experiment monitored vessels undertook normal fishing operations and did not deviate from their normal procedures or fishing locations. Two fishing captains, operating from six different vessels, were voluntary participants in the project. Control and experimental sets occurred in all months of the study except
TABLE 1 Gear characteristics and fishing effort for control (no pingers) and experimental (with pingers) fishing sets observed during the study (April 2009-August 2011). Values are numbers or mean \pm SD (range).

\begin{tabular}{lll}
\hline & Treatment & \\
\cline { 2 - 3 } & No pingers & With pingers \\
\hline No. of sets & 195 & 156 \\
No. of small cetaceans in & 67 & 33 \\
bycatch & & \\
\% sets with small cetacean & 22 & 16 \\
bycatch & & \\
\% sets using bait & 24 & 31 \\
Stretched mesh size $(\mathrm{cm})$ & $19.1,20.3,25.4$ & $19.1,20.3,25.4$ \\
Set duration $(\mathrm{h})$ & $12.7 \pm 2.4$ & $12.7 \pm 2.6$ \\
& $(3.6-19.2)$ & $(2.3-16.4)$ \\
Total soak time $(\mathrm{h})$ & $2,477.75$ & $1,987.65$ \\
Net length $\left(\mathrm{km}^{2}\right)$ & $2.02 \pm 0.33$ & $1.98 \pm 0.36$ \\
& $(1.81-2.96)$ & $(1.64-2.96)$ \\
Net height $(\mathrm{m})$ & $14.2 \pm 0.8$ & $13.9 \pm 0.9$ \\
& $(12.8-14.6)$ & $(12.8-14.6)$ \\
Net area $\left(\mathrm{km}^{2}\right)$ & $0.027 \pm 0.005$ & $0.027 \pm 0.005$ \\
& $(0.023-0.041)$ & $(0.023-0.041)$ \\
Net area time $\left(\mathrm{km}^{2} \mathrm{~h}^{-1}\right)$ & $0.343 \pm 0.090$ & $0.347 \pm 0.093$ \\
& $(0.100-0.751)$ & $(0.053-0.643)$ \\
\hline
\end{tabular}

August 2009 and 2010, when vessels underwent annual maintenance. Vessels either set their nets continuously without pingers (control sets) or with pingers (experimental sets) or alternated between control and experimental sets throughout the course of a fishing trip and also alternated whether the initial set was control or experimental. There was some variation in net characteristics (net length and height) and set duration between control and experimental sets, which was accounted for in the analysis (Table 1).

Dukane Netmark 1000 pingers were used in the study. These pingers are no longer commercially available and were donated to the project. They have a fundamental frequency of $10-12 \mathrm{kHz}$ and emit a $300 \mathrm{~ms}$ tone every 4 seconds with a source level range of c. $120-146 \mathrm{~dB}$ (re: $1 \mu \mathrm{Pa}$ at $1 \mathrm{~m}$; Barlow \& Cameron, 2003). For experimental sets, pingers were attached to the net leadline at a depth of c. $14 \mathrm{~m}$. The urgent need to begin this research (because of high reported bycatch rates) and logistical constraints, meant that pingers available for the trial were limited, and were therefore spaced at $200 \mathrm{~m}$ intervals. Battery voltages were checked before each trip to ensure each pinger was functioning properly. Pingers were also checked after each deployment and any failed units replaced. Data from those sets with failed pingers (six units over five sets, i.e. $3.2 \%$ ) were not included in the analysis.

\section{Data collection}

On-board observers monitored all control and experimental fishing sets. These observers were trained to maintain and 
deploy the pingers and to monitor relevant aspects of the fishery operation as well as the target catch and bycatch of small cetaceans. Observers also recorded the provisioning costs (food, fuel, ice) for each trip and the gross profits received when the catch was landed and sold. Variables included in on-board observer monitoring were the date, time and location of sets as well as the primary gear dimensions and characteristics. The use of blubber from small cetaceans as bait was also monitored. For each fishing set all target catch and bycatch was counted and identified to the species level whenever possible. Bottlenose dolphins Tursiops truncatus were not differentiated between offshore or inshore stock. Neither common dolphins Delphinus spp. nor pilot whales Globicephala spp. were identified to species because of uncertainties in at-sea identification (it is likely, however, that the majority of interactions with common dolphins were with D. capensis; Van Waerebeek, 1994; Mangel et al., 2010). Observers also monitored whether entangled cetaceans were alive or dead at the time of the haul and the final fate of each animal (released alive, discarded dead, used as bait, used for food).

\section{Data analysis}

Pinger effectiveness was assessed using generalized linear mixed models (GLMM). Preliminary models included fixed effects (control sets vs experimental sets, bait use) and random effects (trip, year, season, mesh size, vessel, captain). A random effect weather variable was not included because of missing values but when tested separately this variable was determined to be non-significant. The GLMMs were simplified sequentially to remove non-significant fixed and random effects. The random effect of 'trip' dominated variation in rates of bycatch whereas variance because of the other variables was negligible and these were therefore removed to arrive at the minimal adequate model. The fixed effect 'bait use' was also determined to be non-significant and was removed.

The resulting minimal adequate model for testing the impact of pinger use on bycatch of small cetaceans used a Poisson error distribution with fixed effects (control set vs experiment set) and the random effect (trip) as well as an offset term for fishing effort: offset(log[net area $\times$ time]). This offset term was calculated using the on-board observer data on each set's net area $\left(\mathrm{km}^{2}\right)$ and soak time $(\mathrm{h})$ and was therefore expressed as $\mathrm{km}^{-2} \mathrm{~h}^{-1}$. Use of the log-offset allows the intercept parameters estimated by the GLMMs to be interpreted as catch per unit effort. Small cetacean bycatch data were not overdispersed and model checks confirmed that the Poisson error structure was valid. Seasons were defined as quarter 1 (January-March), quarter 2 (AprilJune), quarter 3 (July-September), and quarter 4 (OctoberDecember). The dependent variable was the total count of small cetaceans captured during a given fishing set.
We also examined the impact of pinger use on the fishery's target catch of sharks and rays. These tests also employed GLMMs and were structured similarly to the tests for small cetaceans described above. However, as shark and ray catch data were highly overdispersed we included an additional individual level random effect term that served to fit the extra-Poisson variation as a normally distributed error around the intercept (Elston et al., 2001). The dependent variable here was the total count of sharks and rays captured during a given fishing set.

Using the GLMMs we were able to calculate the small cetacean and target catch for control and experimental sets. This was accomplished by back-transforming the intercepts of the control and treatment groups to derive the catch per unit effort, which is presented as catch $\mathrm{km}^{-2} \mathrm{~h}^{-1}$.

All GLMMs were fitted using the lme4 package for R v. 2.13.1 (R Development Core Team, 2011). Maps were prepared using ArcMap v. 9.2 (ESRI, Redlands, USA) and the Hawth's Tools Extension (Beyer, 2004). Bathymetric values were obtained from the Global Bathymetric Chart of the Oceans (IOC, IHO \& BODC, 2003). Descriptive statistics are presented as mean $\pm S D$ unless specified otherwise. Trip costs and profits are presented in USD.

\section{Results}

\section{Fishing effort}

Over the 29 months of the study (April 2009-August 2011) we observed 195 control sets over 47 trips and 156 experimental sets over 43 trips (Table 1, Figs 1 \& 2). Blubber of small cetaceans taken from bycatch and harpooned animals was used as bait in $24 \%$ of control sets and $31 \%$ of experimental sets. The mean cost to provision trips was USD 1,020 \pm 669 (range USD 220-4,405, $\mathrm{n}=52$ ) and average gross profits were USD 2,195 $\pm 1,594$ (range USD $0-7,401$ ). Net profits were USD $1,176 \pm 1,468$ (range USD $2,276-6,094)$, with 10 trips $(19.2 \%)$ operating at a loss.

\section{Bycatch of small cetaceans}

Five species of small cetaceans were observed captured, including common dolphins $(\mathrm{n}=45)$, dusky dolphins Lagenorhynchus obscurus $(\mathrm{n}=20)$, bottlenose dolphins $(\mathrm{n}=25)$, Burmesiter's porpoises Phocoena spinipinnis $(\mathrm{n}=8)$ and pilot whales $(\mathrm{n}=2)$. Each of these species was caught in both control and experimental sets, except pilot whales, which were only caught on one occasion in a control set. Forty-five percent of all small cetacean bycatch was common dolphins. All small cetaceans died as a result of their entanglement. Larger bycatch, including bottlenose dolphins and pilot whales, were typically discarded, whereas the majority of dusky dolphins were butchered for use as 


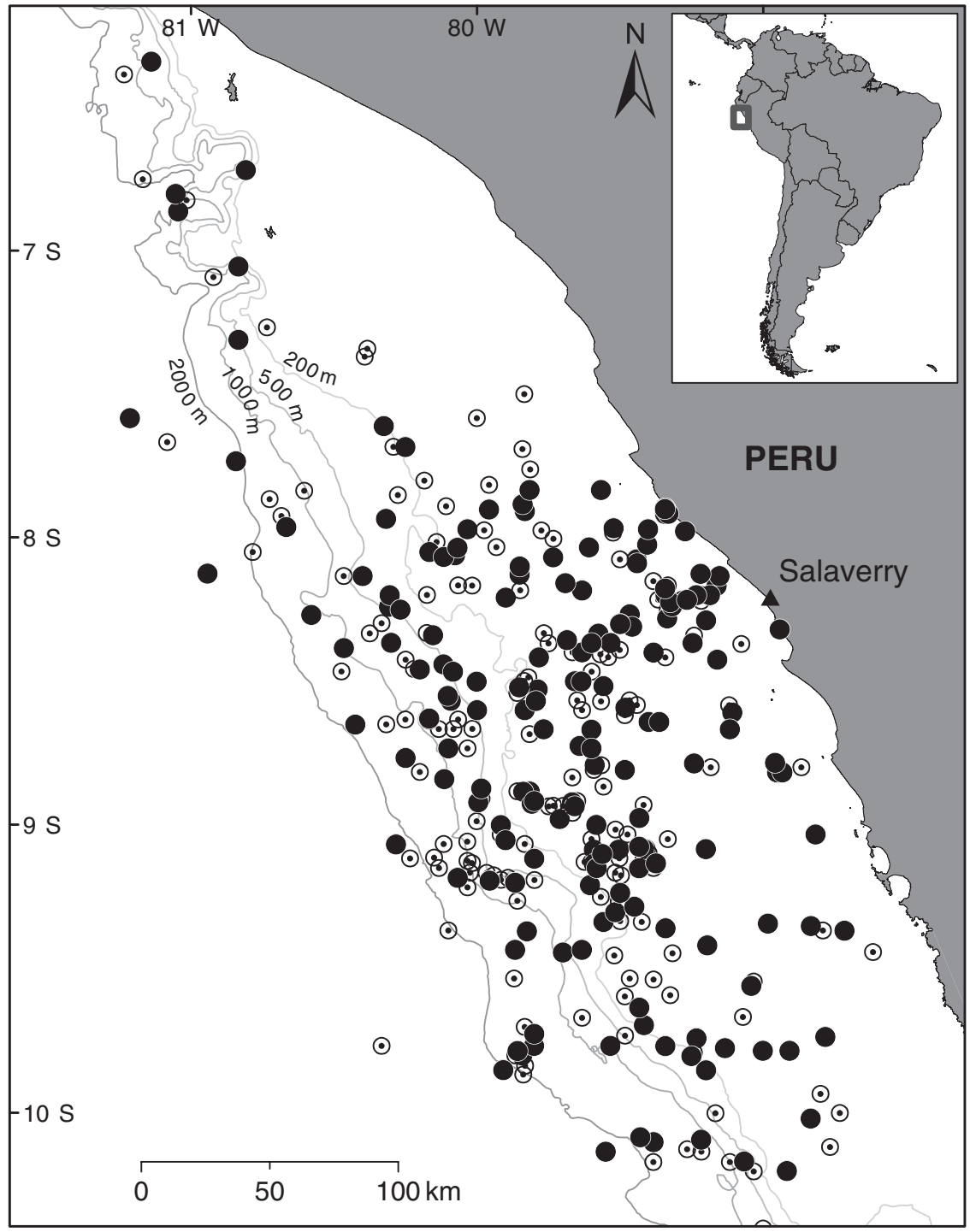

FIG. 1 Locations of control (filled circles) and experimental (open circles) fishing sets observed over the 29 months from April 2009 to August 2011. Fishing vessels participating in the study were based in the port of Salaverry. The rectangle on the inset indicates the location of the main map in Peru.

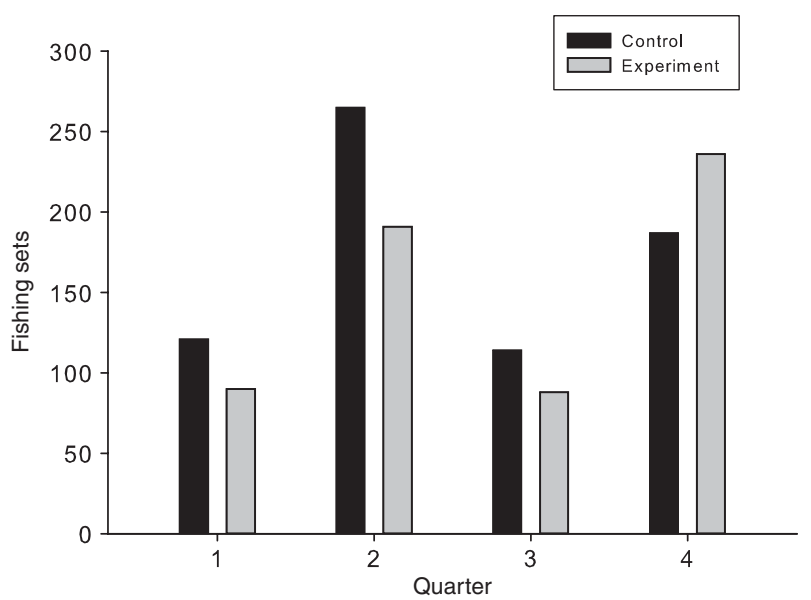

FIG. 2 Distribution of control and experimental sets by monthly quarters over the course of the study (April 2009 to August 2011). Q1, January-March; Q2, April-June; Q3, July-September; Q4, October-December. bait and the majority of Burmeister's porpoises were butchered for use as food (Table 2).

In addition to bycatch, 23 common dolphins and two dusky dolphins were observed to be harpooned, for use as bait on subsequent sets. This typically occurred as vessels were travelling to the fishing ground prior to the first fishing set. Harpooning was infrequent, occurring on 10 trips (11\%) and with 1-4 individuals per event and only on trips primarily targeting blue and mako sharks. Twenty common dolphins were harpooned during seven trips that used pingers and two dusky dolphins and three common dolphins were harpooned during three control trips.

\section{Pinger effectiveness}

A total of 100 small cetaceans were observed captured, 67 during control sets and 33 during experimental sets 
TABLE 2 Species composition of bycatch of small cetaceans for control (no pingers) and experimental (with pingers) fishing sets, and percentage, by species, of final use of the carcasses.

\begin{tabular}{|c|c|c|c|c|c|c|c|}
\hline \multirow[b]{2}{*}{ Species } & \multirow[b]{2}{*}{ Total } & \multicolumn{2}{|l|}{ Treatment } & \multicolumn{4}{|c|}{ Final use (\%) } \\
\hline & & No pingers & With pingers & Discarded $^{1}$ & Bait $^{2}$ & Food $^{3}$ & (n) \\
\hline Delphinus spp. & 45 & 33 & 12 & 41 & 44 & 12 & 34 \\
\hline Lagenorhyncus obscurus & 20 & 11 & 9 & 32 & 58 & 0 & 19 \\
\hline Tursiops truncatus & 25 & 16 & 9 & 67 & 33 & 0 & 18 \\
\hline Phocoena spinipinnis & 8 & 5 & 3 & 43 & 0 & 57 & 7 \\
\hline Globicephala spp. & 2 & 2 & 0 & 100 & 0 & 0 & 2 \\
\hline Total & 100 & 67 & 33 & & & & \\
\hline
\end{tabular}

${ }^{1}$ Animals recovered dead and discarded at sea

${ }^{2}$ Animals recovered dead and then butchered for use as bait during subsequent fishing sets

${ }^{3}$ Animals recovered dead and then butchered for food either for use during the trip or for home consumption

TABLE 3 Per set catch rates for all small cetacean bycatch species by control (no pingers) and experiment (with pingers) treatment groups.

\begin{tabular}{|c|c|c|c|c|c|c|c|c|c|c|}
\hline \multirow[b]{2}{*}{ Species } & \multicolumn{5}{|c|}{ Control } & \multicolumn{5}{|c|}{ Experiment } \\
\hline & 0 & 1 & 2 & 3 & 4 & 0 & 1 & 2 & 3 & 4 \\
\hline Total bycatch & 152 & 23 & 17 & 2 & 1 & 131 & 18 & 6 & 1 & 0 \\
\hline Delphinus spp. & 171 & 16 & 7 & 1 & 0 & 145 & 9 & 2 & 0 & 0 \\
\hline L. obscurus & 187 & 6 & 2 & 0 & 0 & 150 & 4 & 1 & 1 & 0 \\
\hline T. truncatus & 186 & 4 & 3 & 1 & 1 & 149 & 6 & 1 & 0 & 0 \\
\hline P. spinipinnis & 191 & 3 & 1 & 0 & 0 & 154 & 1 & 1 & 0 & 0 \\
\hline Globicephala spp. & 194 & 0 & 1 & 0 & 0 & 156 & 0 & 0 & 0 & 0 \\
\hline
\end{tabular}

(Tables $2 \& 3$, Fig. 3). Twenty-two percent of control sets ( 43 sets) and $16 \%$ of experimental sets (25 sets) had bycatch of small cetaceans. Control sets had a maximum catch of four individuals in a given set whereas experimental sets had a maximum catch of three individuals. Sets using pingers had a $37.2 \%$ lower bycatch rate of small cetaceans and this difference was statistically significant (GLMM, $\chi_{1}^{2}=4.0158$, $\mathrm{P}=0.0450$; Table 4, Fig. 4). The bycatch rate declined from $0.798 \mathrm{~km}^{-2} \mathrm{~h}^{-1}$ (range \pm 1 SE $0.678-0.939$ ) for control sets to $0.502 \mathrm{~km}^{-2} \mathrm{~h}^{-1}$ (range \pm 1 SE $0.407-0.619$ ) for experimental sets. There were declines in bycatch rates of each small cetacean species but none of these declines were statistically significant (Tables 3 \& 4, Fig. 4).

Control sets had a target catch rate of 18.6 sharks $\mathrm{km}^{-2} \mathrm{~h}^{-1}$ (range \pm 1 SE 14.0-24.7) whereas experimental sets had a catch of 26.3 sharks $\mathrm{km}^{-2} \mathrm{~h}^{-1}$ (range \pm 1 SE 19.7-35.0) but this difference was not statistically significant (GLMM, $\chi_{1}^{2}=2.9157, \mathrm{P}=0.088$, Table 4, Fig. 5). Likewise, there was no statistical difference in the catch rates of rays between control sets (GLMM, $\left.\chi_{1}^{2}=0.0534, \mathrm{P}=0.82\right)$ and experimental sets (Table 4, Fig. 5), with catch rates of $0.001 \mathrm{~km}^{-2} \mathrm{~h}^{-1}$ and $0.002 \mathrm{~km}^{-2} \mathrm{~h}^{-1}$, respectively.

\section{Discussion}

Because of the nature of small-scale fisheries (i.e. minimal management or enforcement, economic and political marginalization), efforts to identify, test and implement bycatch mitigation measures have proven challenging (Campbell \& Cornwelles, 2008; Soykan et al., 2008). Here, in the first study of its kind in the south-eastern Pacific Ocean, we tested pinger effectiveness and have shown that they reduced bycatch of small cetaceans in the Peruvian small-scale driftnet fishery. As was observed in the California drift gill-net fishery for swordfish and sharks, the reduction was most pronounced when assessing total bycatch of small cetaceans (Barlow \& Cameron, 2003). Given the modest sample size in our study and the relative rarity of bycatch events, the observed declines in bycatch at the species level were not statistically significant. Although use of pingers did reduce the bycatch rate by $37 \%$, it did not eliminate it. The greatest decline in bycatch rate was observed for common dolphins ( $44 \%$ decline), similar to the c. $50 \%$ decline observed in the California drift gill-net fishery for 1990-2009 (Carretta \& Barlow, 2011), but c. half the $86 \%$ decline observed in a controlled pinger experiment in the same fishery for the period 1996-1997 (Barlow \& Cameron, 2003).

\section{Pinger effectiveness}

How pingers work to reduce small cetacean captures in nets is still unclear (Kraus et al., 1997; Carlström et al., 2002; Morton, 2002). The range at which these devices may be audible is known to be variable and subject to environmental conditions such as sea condition and water 
TABLE 4 Mean catch rates $\left(\mathrm{km}^{-2} \mathrm{~h}^{-1}\right.$, with range $\pm 1 \mathrm{SE}$, derived from the generalized linear mixed models used to test pinger effectiveness) of bycatch (dolphins and porpoises) and target catch (sharks and rays) for all observed control (no pingers) and experimental (with pingers) sets from April 2009 to August 2011, and \% change in catch rate between control and experimental sets, and associated P-values.

\begin{tabular}{|c|c|c|c|c|c|c|}
\hline \multirow[b]{2}{*}{ Species } & \multicolumn{2}{|c|}{ No pingers } & \multicolumn{2}{|c|}{ With pingers } & \multirow[b]{2}{*}{$\%$ change } & \multirow[b]{2}{*}{$\mathrm{P}$} \\
\hline & Mean & range $\pm 1 \mathrm{SE}$ & Mean & range $\pm 1 \mathrm{SE}$ & & \\
\hline \multicolumn{7}{|c|}{ Dolphins \& porpoises } \\
\hline Total & 0.798 & $(0.678-0.939)$ & 0.502 & $(0.407-0.619)$ & -37.2 & 0.045 \\
\hline Delphinus spp. & 0.289 & $(0.225-0.372)$ & 0.160 & $(0.114-0.226)$ & -44.6 & 0.093 \\
\hline L. obscurus & 0.048 & $(0.029-0.080)$ & 0.043 & $(0.025-0.073)$ & -10.4 & 0.827 \\
\hline T. truncatus & 0.051 & $(0.030-0.085)$ & 0.031 & $(0.017-0.056)$ & -39.4 & 0.360 \\
\hline P. spinipinnis & 0.001 & $(0.000-0.009)$ & 0.000 & $(0.000-0.004)$ & -75.0 & 0.379 \\
\hline Globicephala spp. & 0.000 & $(0.000-0.092)$ & 0.000 & & -100.0 & 0.692 \\
\hline \multicolumn{7}{|l|}{ Sharks \& rays } \\
\hline Sharks & 18.6 & $(14.0-24.7)$ & 26.3 & $(19.7-35.0)$ & 29.3 & 0.088 \\
\hline Rays & 0.001 & $(0.000-0.007)$ & 0.002 & $(0.000-0.009)$ & 22.2 & 0.817 \\
\hline
\end{tabular}
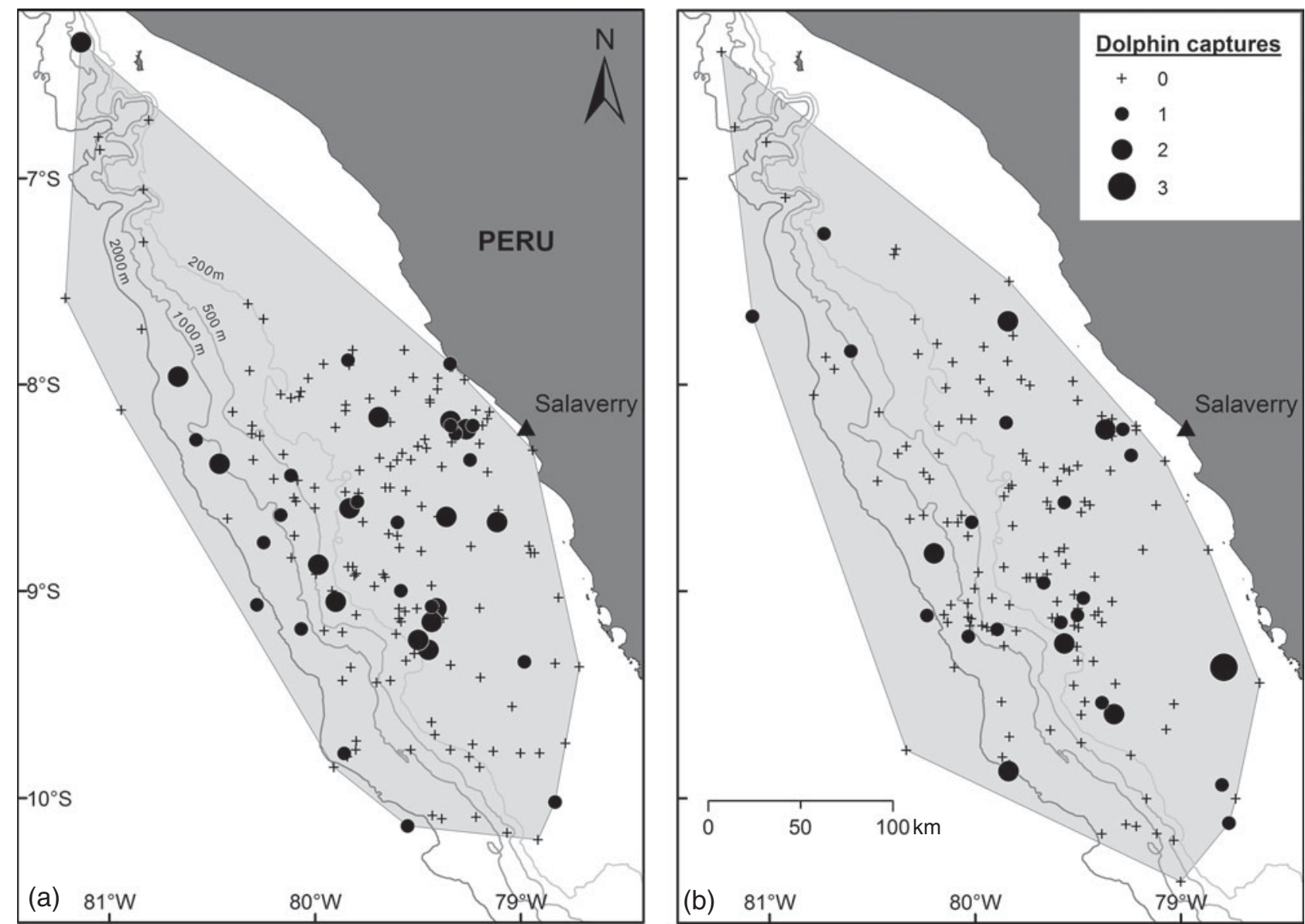

FIG. 3 Locations and quantities of small cetacean bycatch in (a) control and (b) experimental sets. The shaded area is the minimum convex polygon of fishing sets.

temperature (Trippel et al., 1999; Carlström et al., 2002). Dolphins and porpoises have been shown to alter their behaviour or distribution in the presence of pingers (Cox et al., 2003; Carlström et al., 2009). Experiments with Dukane 1000 pingers have indicated that they are probably audible under favourable weather conditions at a range of
$600 \mathrm{~m}$ (Trippel et al., 1999) and lead to reduced echolocations in harbour porpoises Phocoena phocoena at $500 \mathrm{~m}$ (Carlström et al., 2009).

The appropriate spacing of pingers has been subject to some debate and recommendations vary (Bordino et al., 2002; Barlow \& Cameron, 2003; Larsen \& Krog, 2007; Gazo 

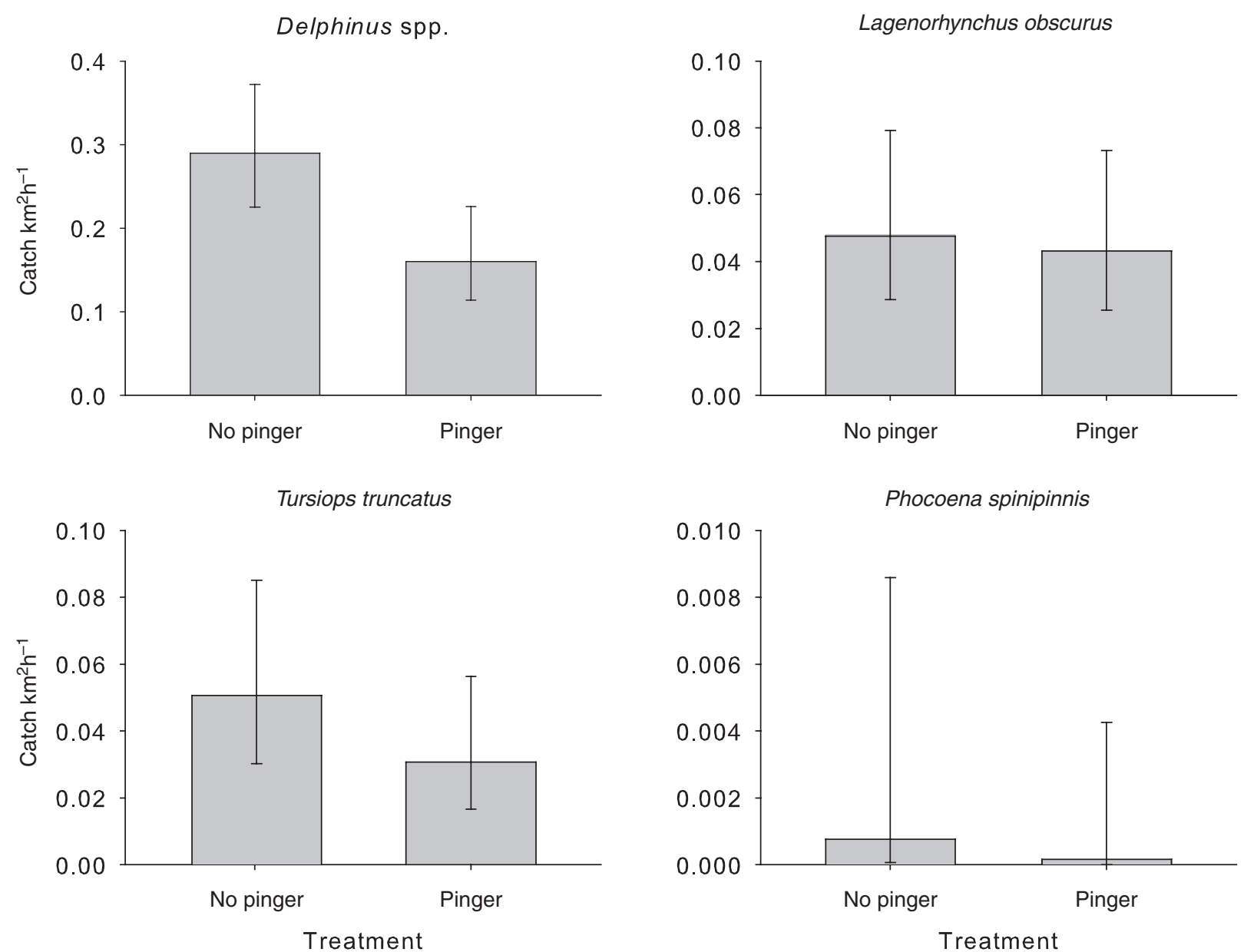

FIG. 4 Bycatch rates (catch $\mathrm{km}^{2} \mathrm{~h}^{-1}$ ), with SE bars, of the main four small cetacean species for control (no pinger) and experimental sets (pinger).

et al., 2008; Gönener \& Bilgin, 2009). Spacing has sometimes been in excess of the manufacturer's recommendations (Larsen \& Krog, 2007; Gazo et al., 2008; Gönener \& Bilgin, 2009). We spaced pingers at $200 \mathrm{~m}$ apart in an attempt to balance pinger effectiveness and the project's logistical constraints. Pinger spacing was also of concern because the relatively high costs of pingers in relation to income levels in this fishery had implications for economic viability, implementation and monitoring. The $37 \%$ decrease in small cetacean bycatch rate that we observed was less than that observed in other studies, where reductions were c. 50-90\% (Kraus et al., 1997; Bordino et al., 2002; Barlow \& Cameron, 2003; Carretta et al., 2008; Carretta \& Barlow, 2011). The reasons for differences between studies include variations in fishery characteristics and net type, target and bycatch species, abundance and group size, and pinger specifications, as well as varying methods used to calculate bycatch rates. There have also been declines observed in pinger effectiveness between controlled studies and actual implementation, including in the California driftnet fishery (Carretta \& Barlow, 2011) and the US north-east gill-net fishery (Palka et al., 2008). Nevertheless, further reductions in the bycatch rate of small cetaceans in Peru may be possible with reduced pinger spacing, as there is evidence that bycatch rates decrease as the number of pingers increases (Trippel et al., 1999; Barlow \& Cameron, 2003) and that bycatch rates can increase in sets with less than the prescribed number of operational pingers (Palka et al., 2008; Carretta \& Barlow, 2011).

We did not observe bycatch of pinnipeds, although South American sea lions Otaria flavescens and fur seals Arctocephalus australis are common on the fishing grounds and are known to depredate catch from fishing nets. Concerns have been raised that the sound emitted by pingers could increase depredations by pinnipeds by alerting them to the presence of nets, commonly referred to as the 'dinner bell' effect (Dawson, 1991). A review of 19 years of on-board observer data from the California driftnet fishery found evidence of an increase in depredations by pinnipeds after pingers were introduced but attributed that increase to changes in target catch rates and pinniped populations, rather than to attraction to the net by the pingers (Carretta \& Barlow, 2011). The systematic monitoring of depredations by pinnipeds was beyond the 

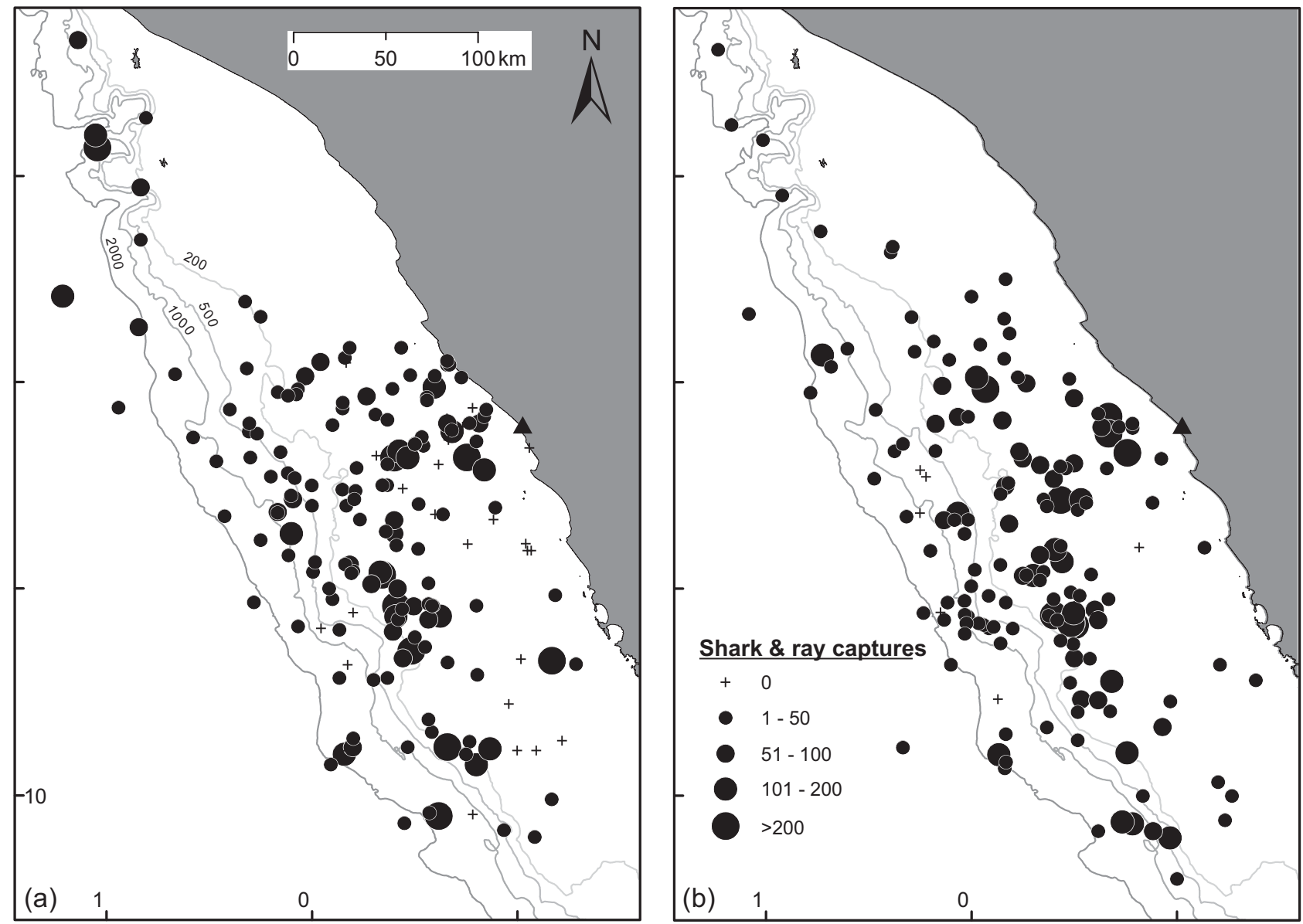

FIG. 5 Locations and quantities of shark and ray catch in (a) control and (b) experimental sets.

scope of our study as there was some uncertainty regarding the ability to identify depredation events accurately and consistently. It should, however, be monitored in the future as the effectiveness of pingers could be undermined if catch values declined as a result of increased damage from pinnipeds and other species (Kraus et al., 1997; Bordino et al., 2002; Carretta \& Barlow, 2011).

There was no statistically significant difference in catch rates of sharks and rays, the primary target species in this fishery, between control and experimental sets. This finding is in line with other pinger trials that have shown either no impact on target catch (Kraus et al., 1997; Trippel et al., 1999; Bordino et al., 2002; Carlström et al., 2002; Gazo et al., 2008; Gönener \& Bilgin, 2009) or an improved target catch (Buscaino et al., 2009). The lack of an impact in our study is not unexpected as shark hearing is typically in the 40-800 Hz range (Myrberg, 2001), well below the $10 \mathrm{KHz}$ fundamental frequency of the Dukane pingers. Moreover, while sharks and small cetaceans are typically considered as having a predator-prey relationship, given the species and small sizes (c. $1 \mathrm{~m}$; ProDelphinus, unpubl. data) of sharks typically captured in the fishery it may be more accurate to consider them as primarily competitors for prey (Heithaus, 2001).

\section{Regional significance and barriers to implementation}

The significance of the declines in bycatch rate associated with pinger use become clear when one considers the potential regional-level impacts. Peruvian small-scale fisheries grew during $1995-2005$ by c. $50 \%$ to 9,667 vessels, of which the largest component (30\% of the fleet) is gill-net vessels (Escudero, 1997; Estrella et al., 1999, 2000; Estrella \& Swartzman, 2010; Alfaro-Shigueto et al., 2011). The annual mortality of small cetaceans in the operations of the Peruvian small-scale driftnet fleet is estimated to be 15,000-20,000 (Mangel et al., 2010). Mortality of small cetaceans for the port of Salaverry alone was estimated to average 2,412 animals per annum for 2002-2007 (Mangel et al., 2010). Given the catch rates reported here and the level of annual fishing effort for the port of Salaverry, c. 4,000 sets (Mangel et al., 2010), one could expect a reduction in bycatch of small cetaceans of $c .500$ individuals per year if all driftnet vessels from the port used pingers. As the Salaverry gill-net fleet represents c. $2 \%$ of gill-net fishing effort in Peru (Escudero, 1997; Estrella et al., 1999, 2000; Estrella \& Swartzman, 2010; Mangel et al., 2010), and that fleet deploys at least 100,000 km of net annually (Alfaro-Shigueto et al., 2010), use of pingers by gill-net vessels throughout Peru has 
the potential to reduce small cetacean mortalities by thousands of animals each year.

Significant barriers to implementation do, however, exist. The current unit cost of commercially available pingers is c. USD 130 per unit and the recommended spacing is generally $200 \mathrm{~m}$ (Northridge et al., 2010). To equip a $2 \mathrm{~km}$ length net in this fishery would require an investment of c. USD 1,100-1,500. As we report here, this is approximately equivalent to the mean net profit of a fishing trip. These profits are divided between captain, crew and owner so the portion left to fund the purchase of pingers would take multiple trips to offset.

The pingers that are currently commercially available are durable and typically have estimated battery lives of thousands of hours to multiple years. These characteristics are particularly important for utilization by a small-scale fleet, where vessels are numerous and dispersed among many, often remote, locations. Under such conditions pinger or battery replacements would be difficult to find and this could lead to increased failure to use pingers appropriately. But there would still be unavoidable costs, however small, associated with maintaining pingers (e.g. battery replacement, pinger damage and loss). Whether vessel owners in this fishery would be willing to accept all the costs associated with purchasing and maintaining pingers in a management environment in which enforcement is minimal is questionable. Small cetaceans are still regularly captured, consumed and sold, in violation of regulations (Van Waerebeek et al., 2002; Mangel et al., 2010). Other than a new effort for regulation and enforcement, which is unlikely, the available levers by which to mandate pinger use are limited. As a result, promotion and uptake of pinger use in the fishery will probably begin on a voluntary basis and build upon positive experiences of other fishers. In such situations product cost and ease of use become important factors that could help determine broader acceptance in the fishery. As Alfaro-Shigueto et al. (2010) note, gill-net fisheries in Peru can be thought of as entry-level or 'gateway' fisheries because of their relatively low costs and profits in comparison to other fisheries such as long-line fisheries. Any efforts to promote pinger use should therefore also stress the potential benefits to work efficiency. Reduced net damage associated with pinger use has been reported (Culik et al., 2001; Gazo et al., 2008; Buscaino et al., 2009). Moreover, confirming the observation in Mangel et al. (2010), we found that c. $50 \%$ of all bycatch of dolphins and porpoises was discarded, a potential source of net damage and lost time and effort associated with disentanglement.

The use of small cetaceans for bait is widespread globally (Dolar, 1994; Goodall et al., 1994; Lescrauwaet \& Gibbons, 1994; Zavala-Gonzalez et al., 1994; Mora-Pinto et al., 1995; Van Waerebeek et al., 1997; Avila et al., 2008; Mangel et al., 2010). We observed harpooning of dolphins for use as bait on $11 \%$ of trips. There is clearly a need to continue monitoring this dynamic as continued harpooning would offset some of the gains made through pinger use. Under the currently limited monitoring and enforcement of the ban on capture and trade of small cetaceans, the regular use of dolphins for bait will probably continue.

\section{Conclusions and recommendations}

We have shown that pingers were effective at reducing bycatch of small cetaceans in the Peruvian small-scale driftnet shark fishery. Given the vast size of this fishery and its current levels of bycatch of small cetaceans (AlfaroShigueto et al., 2010; Mangel et al., 2010) appropriate use of pingers could result in mortality reductions of thousands of individuals per annum and would represent an important step for the conservation of small cetaceans in the southeastern Pacific. Further collaborative research with fishermen and vessel owners in the Peruvian gill-net fishery are currently underway and will continue to monitor pinger effectiveness and their impacts on small cetaceans and the fishery (e.g. target catch rates, depredations by pinnipeds).

As the pingers used in this study are no longer commercially available, an alternative will have to be found if larger-scale trials are to occur. The current suite of commercially available pingers each has specific design specifications and are not necessarily inter-changeable, and therefore their suitability for the Peruvian small-scale driftnet fishery needs to be assessed prior to large-scale implementation.

Additional challenges to large-scale implementation remain, including the costs associated with pingers and their maintenance, and the continued practice of harpooning of dolphins for use as bait. These issues will have to be addressed before expanding pinger use to the national level and to achieve the full extent of potential reductions in mortality of dolphins and porpoises.

\section{Acknowledgements}

We thank the participating fishermen and field observers for their generous collaboration. ProDelphinus biologists Natalia Ortiz and Graciela McEvoy helped with field work. Project funding and equipment was provided by Cetacean Society International, Chelonia Ltd, Cleveland Metroparks Zoo, Comisión Permanente del Pacífico Sur, the Darwin Initiative, the Oak Foundation through Duke University, the Rufford Foundation and the Whale and Dolphin Conservation Society, as well as Dr Andy Read of Duke University and Dr Per Berggren of Newcastle University. The manuscript benefited from helpful comments by two anonymous reviewers. JCM and JA-S are Overseas Research and Students Awards Scheme (ORSAS) and University of 
Exeter scholarship awardees, respectively. MJW is funded by the Peninsula Research Institute for Marine Renewable Energy (PRIMaRE). DH is supported by the Natural Environment Research Council and the European Union. BJG receives funding from the Darwin Initiative, the Natural Environment Research Council and the European Union.

\section{References}

Alfaro-Shigueto, J., Mangel, J.C., Bernedo, F., Dutton, P.H., Seminoff, J.A. \& Godley, B.J. (2011) Small-scale fisheries of Peru: a major sink for marine turtles in the Pacific. Journal of Applied Ecology, 48, 1432-1440.

Alfaro-Shigueto, J., Mangel, J.C., Pajuelo, M., Dutton, P.H., Seminoff, J.A. \& Godley, B.J. (2010) Where small can have a large impact: structure and characterisation of small-scale fisheries in Peru. Fisheries Research, 106, 8-17.

Avila, I.C., Garcia, C. \& Bastidas, J.C. (2008) A note on the use of dolphins as bait in the artisanal fisheries off Bahía Solano, Chocó, Colombia. Journal of Cetacean Research and Management, 10, 179-182.

Awrerman, J.A., Huyvaert, K.P., Mangel, J., Shigueto, J.A. \& ANDERSON, D.J. (2006) Incidental and intentional catch threatens Galapagos waved albatross. Biological Conservation, 133, 483-489.

Barlow, J. \& Cameron, G.A. (2003) Field experiments show that acoustic pingers reduce marine mammal bycatch in the California drift gill net fishery. Marine Mammal Science, 19, 265-283.

Béné, C. (2006) Small-scale Fisheries: Assessing their Contribution to Rural Livelihoods in Developing Countries. FAO Fisheries Circular No. 1008. Food and Agriculture Organization of the UN, Rome, Italy.

Berkes, F., Mahon, R., McConney, P., Pollnac, R. \& Pomeroy, R. (2001) Managing Small-scale Fisheries: Alternative Directions and Methods. International Development Research Centre, Ottawa, Canada.

Beyer, H.L. (2004) Hawth's analysis tools for ArcGIS. Http://www. spatialecology.com/htools [accessed 8 February 2013].

Bordino, P., Kraus, S., Albareda, D., Fazio, A., Palmerio, A., Mendez, M. \& Botta, S. (2002) Reducing incidental mortality of Franciscana dolphin Pontoporia blainvillei with acoustic warning devices attached to fishing nets. Marine Mammal Science, $18,833-842$.

Buscaino, G., Buffa, G., Sara, G., Bellante, Jr, A., Tonnelle, A.J., Hardt, F.A.S. et al. (2009) Pinger affects fish CATCH EFFICIENCY AND DAMAGE TO BOTTOM GILL NETS RELATED TO BOTTLENOSE DOLPHINS. FISHERIES SCIENCE, 75, 537-544.

Campbell, L.M. \& Cornwelles, M.L. (2008) Human dimensions of bycatch reduction technology: current assumptions and directions for future research. Endangered Species Research, 5, 325-334.

Carlström, J., Berggren, P., Dinnetz, F. \& Borjesson, P. (2002) A field experiment using acoustic alarms (pingers) to reduce harbour porpoise by-catch in bottom-set gillnets. ICES Journal of Marine Science, 59, 816-824.

Carlström, J., Berggren, P. \& Tregenza, N.J.C. (2009) Spatial and temporal impact of pingers on porpoises. Canadian Journal of Fisheries and Aquatic Science, 66, 72-82.

Carretta, J.V. \& Barlow, J. (2011) Long-term effectiveness, failure rates, and 'dinner bell' properties of acoustic pingers in a gillnet fishery. Marine Technology Society Journal, 45, 7-19.

Carretta, J.V., Barlow, J. \& Enriquez, L. (2008) Acoustic pingers eliminate beaked whale bycatch in a gill net fishery. Marine Mammal Science, 24, 956-961.
Chuenpagdee, R., Liguori, L., Palomares, M.L.D. \& Pauly, D. (2006) Bottom-Up, Global Estimates of Small-Scale Marine Fisheries Catches. Fisheries Centre Research Reports, Vancouver, Canada.

Clarke, R. (1962) Whale observation and whale marking off the coast of Chile in 1958 and from Ecuador towards and beyond the Galapagos Islands in 1959. Norsk Hvalfangst-Tidende, $7,265-287$.

Cox, T.M., Read, A.J., Swanner, D., Urian, K. \& Waples, D. (2003) Behavioral responses of bottlenose dolphins, Tursiops truncatus, to gillnets and acoustic alarms. Biological Conservation, 115, $203-212$.

Culik, B.M., Koschinski, S., Tregenza, N. \& Ellis, G.M. (2001) Reactions of harbor porpoises Phocoena phocoena and herring Clupea harengus to acoustic alarms. Marine Ecology Progress Series, 211, 255-260.

DAwson, S.M. (1991) Modifying gillnets to reduce entanglements of cetaceans. Marine Mammal Science, 7, 274-282.

Dawson, S.M. \& SLooten, E. (2005) Management of gillnet bycatch of cetaceans in New Zealand. Journal of Cetacean Research and Management, 7, 59-64.

Dolar, L.L. (1994) Incidental Takes of Small Cetaceans in Fisheries in Palawan, Central Visayas and Northern Mindanao in the Philippines. International Whaling Commission, Cambridge, UK.

Dutton, P.H. \& Squires, D. (2008) Reconciling biodiversity with fishing: a holistic strategy for Pacific sea turtle recovery. Ocean Development and International Law, 39, 200-222.

Elston, D.A., Moss, R., Boulinier, T., Arrowsmith, C. \& LAMBin, X. (2001) Analysis of aggregation, a worked example: numbers of ticks on red grouse chicks. Parasitology, 122, 563-569.

Escudero, L. (1997) Encuesta estructural de la pesquería artisanal del litoral Peruano. Informe Progresivo del Instituto del Mar del Peru 59 (Junio), Instituto del Mar del Peru, Lima, Peru.

Estrella, C., Guevara-Carrasco, R., Avila, W., Palacios, J. \& Medina, A. (1999) Informe estadístico de los recursos hidrobiológicos de la pesca artisanal por especies, artes, meses y caletas durante el primer semestre de 1999. Informe del Instituto del Mar del Peru, 148, 1-214.

Estrella, C., Guevara-Carrasco, R., Avila, W., Palacios, J. \& Medina, A. (2000) Informe estadístico de los recursos hiarobiológicos de la pesca artesanal por especies, artes, meses y caletas durante el segundo semestre de 1999. Informe del Instituto del Mar del Peru, 151, 1-194.

Estrella, C. \& Swartzman, G. (2010) The Peruvian artisanal fishery: changes in patterns and distribution over time. Fisheries Research, 101, 133-145.

European Commission (2004) Council Regulation (EC) No 812/2004 of 26.4.2004 laying down measures concerning incidental catches of cetaceans in fisheries and amending Regulation (EC) No 88/98. Official Journal of the European Union, 47, 12-31.

Gazo, M., Gonzalvo, J. \& A guilar, A. (2008) Pingers as deterrents of bottlenose dolphins interacting with trammel nets. Fisheries Research, 92, 70-75.

Gönener, S. \& Bilgin, S. (2009) The effect of pingers on harbour porpoise, Phocoena phocoena bycatch and fishing effort in the turbot gill net fishery in the Turkish Black Sea coast. Turkish Journal of Fisheries and Aquatic Sciences, 9, 151-157.

Goodall, R.N.P., Schiavini, A.C.M. \& Fermani, C. (1994) Net Fisheries and Net Mortality of Small Cetaceans off Tierra del Fuego, Argentina. International Whaling Commission, Cambridge, UK.

Heithaus, M.R. (2001) Predator-prey and competitive interactions between sharks (order Selachii) and dolphins (suborder Odontoceti): a review. Journal of Zoology, 253, 53-68.

IOC, IHO \& BODC (2003) Centenary Edition of the GEBCO Digital Atlas. Published on CD-ROM on behalf of the Intergovernmental 
Oceanographic Commission and the International Hydrographic Organization as part of the General Bathymetric Chart of the Oceans, British Oceanographic Data Centre, Liverpool, UK.

Jacquet, J. \& Pauly, D. (2008) Funding priorities: big barriers to small-scale fisheries. Conservation Biology, 22, 832-835.

Jaramillo-Legorreta, A., Rojas-Bracho, L., Brownell, Jr, R.L., Read, A.J., Reeves, R.R., Ralls, K. \& Taylor, B.L. (2007) Saving THE VAQUiTA: IMMEDIATE ACTION, NOT MORE DATA. CONSERVATION BIOLOGY, 21, 1653-1655.

Jefferson, T.A. \& Curry, B.E. (1994) A global review of porpoise (Cetacea: Phocoenidae) mortality in gillnets. Biological Conservation, 67, 167-183.

Kraus, S.D., Read, A.J., Solow, A., Baldwin, K., Spradlin, T., Anderson, E. \& Williamson, J. (1997) Acoustic alarms reduce porpoise mortality. Nature, 388,525 .

Larsen, F. \& Krog, C. (2007) Fishery trials with increased pinger spacing. Document $\mathrm{SC} / 59 / \mathrm{SM}_{2}$ presented to the meeting of the Scientific Committee of the International Whaling Commission, Anchorage, Alaska, 7-8 May 2007. The International Whaling Commission, Cambridge, UK.

Lescraumaet, A. \& Gibbons, J. (1994) Mortality of small cetaceans and the crab bait fishery in the Magallanes Area of Chile since 1980. Report of the International Whaling Commission (Special Issue), 15, 485-494.

Lewison, R.L., Crowder, L.B., Read, A.J. \& Freeman, S.A. (2004) Understanding impacts of fisheries bycatch on marine megafauna. Trends in Ecology \& Evolution, 19, 598-604.

Ley General de Pesca (2001) Reglamento de la ley general de pesca. Decreto Supremo \#012-2001-PE. Titulo 3, Capitulo 2, Articulo 30, Peru.

Mangel, J.C., Alfaro-Shigueto, J., Waerebeek, K.V., Cáceres, C., Bearhop, S., Witt, M.J. \& Godley, B.J. (2010) Small cetacean captures in Peruvian artisanal fisheries: high despite protective legislation. Biological Conservation, 143, 136-143.

McGoodwin, J.R. (2001) Understanding the Cultures of Fishing Communities: A Key to Fisheries Management and Food Security. Food and Agriculture Organization of the UN, Rome, Italy.

Mora-Pinto, D.M., Mufioz-Hincapie, M.F., Mignucci-Giannoni, A.A. \& Acero-Pizarro, A. (1995) Marine mammal mortality and strandings along the Pacific Coast of Colombia. Report of the International Whaling Commission, 45, 427-429.

Moreno, C.A., Arata, J.A., Rubilar, P., Hucke-Gaete, R. \& Robertson, G. (2006) Artisanal longline fisheries in southern Chile: lessons to be learned to avoid incidental seabird mortality. Biological Conservation, 127, 27-36.

Morton, A. (2002) Displacement of Orcinus orca (L.) by high amplitude sound in British Columbia, Canada. ICES Journal of Marine Science, 59, 71-80.

Myrberg, A.A. (2001) The acoustical biology of Lamellibranchia. Environmental Biology of Fishes, 60, 31-45.

NOAA \& NMFS (1997) Taking marine mammals incidental to commercial fishing operations; Pacific offshore cetacean take reduction plan. Final rule. Federal Register, Rules and Regulations, 62, 51805-51814. Published by the Office of the Federal Register, National Archives and Records Administration, Washington, DC, USA.

NOAA \& NMFS (1998) Taking marine mammals incidental to commercial fishing operations; harbour porpoise take reduction plan. Final rule. Notice of availability of take reduction plan. Federal Register, Rules and Regulations, 63, 66464-66490. Published by the Office of the Federal Register, National Archives and Records Administration, Washington, DC, USA.
Northridge, S., Fortuna, C. \& Read, A. (2010) Guidelines for Technical Measures to Minimise Cetacean-Fishery Conflicts in the Mediterranean and Black Seas. Document ACCOBAMS-MOP $4 /$ 2010/Inf39. Agreement on the Conservation of Cetaceans of the Black Sea, Mediterranean Sea and contiguous Atlantic Area. Fourth Meeting of the Contracting Parties, 9-12 November 2010, Monaco. Palka, D.L., Rossman, M.C., Vanatten, A.S. \& Orphanides, C.D. (2008) Effect of pingers on harbour porpoise (Phocoena phocoena) bycatch in the US Northeast gillnet fishery. Journal of Cetacean Research and Management, 10, 217-226.

Peckham, S.H., Diaz, D.M., Walli, A., Ruiz, G., Crowder, L.B. \& Nichols, W.J. (2007) Small-scale fisheries bycatch jeopardizes endangered Pacific loggerhead turtles. PLOS ONE, 2, e1041.

Perrin, W.F., Donovan, G.P. \& Barlow, J. (eds) (1994) Report of the International Whaling Commission (Special Issue 15). Gillnets and Cetaceans. International Whaling Commission, Cambridge, UK.

R Development Core Team (2011) R: A Language and Environment for Statistical Computing. R Foundation for Statistical Computing, Vienna, Austria.

READ, A.J. (2008) The looming crisis: interactions between marine mammals and fisheries. Journal of Mammalogy, 89, 541-548.

Read, A.J., Drinker, P. \& Northridge, S. (2006) Bycatch of marine mammals in U.S. and global fisheries. Conservation Biology, 20, 163-169.

Read, A.J., Waerebeek, K.V., Reyes, J., McKinnon, J.S. \& LeHMAN, L. (1988) The exploitation of small cetaceans in coastal Peru. Biological Conservation, 46, 53-70.

Reeves, R.R., Smith, B.D., Crespo, E.A. \& Notarbartolo di Sciara, G. (eds) (2003) Dolphins, Whales and Porpoises: 2002-2010 Conservation Action Plan for the World's Cetaceans. IUCN, Gland, Switzerland, and Cambridge, UK.

Soykan, C.U., Moore, J.E., Zydelis, R., Crowder, L.B., Safina, C. \& LEWISON, R.L. (2008) Why study bycatch? An introduction to the theme section on fisheries bycatch. Endangered Species Research, 5 , 91-102.

Trippel, E.A., Strong, M.B., Terhune, J.M. \& Conway, D. (1999) Mitigation of harbour porpoise (Phocoena phocoena) by-catch in the gillnet fishery in the lower Bay of Fundy. Canadian Journal of Fisheries and Aquatic Sciences, 56, 113-123.

Van Waerebeek, K. (1994) A note on the status of the dusky dolphins (Lagenorhynchus obscurus) off Peru. Report of the International Whaling Commission (Special Issue), 15, 525-527.

Van Waerebeek, K., Alfaro-Shigueto, J., Montes, D., Onton, K., Santillan, L., Bressem, M.F.V. \& Vega, D. (2002) Fisheries Related Mortality of Small Cetaceans in Neritic Waters of Peru in 1999-2001. Document SC/54/SM1o presented to the meeting of the Scientific Committee of the International Whaling Commission, Shimonoseki, Japan, 20-24 May 2002. The International Whaling Commission, Cambridge, UK.

Van Waerebeek, K., Bressem, M.F.V., Felix, F., Alfaro-Shigueto, J., Garcia-Godos, A., ChavezLisambart, L. et al. (1997) Mortality of dolphins and porpoises in coastal fisheries off Peru and southern Ecuador in 1994. Biological Conservation, 81, 43-49.

Van Waerebeek, K. \& Reyes, J.C. (1990) Catch of small cetaceans at Pucusana Port, central Peru, during 1987. Biological Conservation, 51, 15-22.

Van Waerebeek, K. \& Reyes, J.C. (1994) Post-ban small cetaceans takes off Peru: a review. Report of the International Whaling Commission, 15, 503-519.

Zavala-GonZalez, A., Urban-Ramirez, J. \& Esquivel-Macias, C. (1994) A note on artisanal fisheries interactions with small cetaceans in Mexico. Report of the International Whaling Commission (Special Issue), 15, 235-237. 


\section{Biographical sketches}

Jeffrey Mangel and Joanna Alfaro-Shigueto operate the Peruvian NGO ProDelphinus whose work focuses on monitoring and mitigating the bycatch of threatened marine fauna in small-scale fisheries. MAтTHEW W IтT is researching spatial ecology as an aid to understanding marine vertebrate distribution and foraging ecology. DAVE HODGSON is a quantitative ecologist focusing on the robustness of empirical models on population and community dynamics, with applications for conservation management and the exploitation of natural resources. BRENDAN GODLEY has wide-ranging interests in biodiversity conservation and especially the study of marine vertebrates. 